\title{
Interactions between Parasitic Infections and Reproductive Efficiency in Horses
}

\author{
Panagiota Tyrnenopoulou ${ }^{1}$, , Petros T. Boufis ${ }^{1}$, George C. Fthenakis ${ }^{1, *}$ and Elias Papadopoulos ${ }^{2}$ (D) \\ 1 Veterinary Faculty, University of Thessaly, 43100 Karditsa, Greece; ptyrnenop@vet.uth.gr (P.T.); \\ pboufisvet@gmail.com (P.T.B.) \\ 2 Laboratory of Parasitology and Parasitic Diseases, Faculty of Health Sciences, School of Veterinary Medicine, \\ Aristotle University of Thessaloniki, 54124 Thessaloniki, Greece; eliaspap@vet.auth.gr \\ * Correspondence: gcf@vet.uth.gr
}

check for updates

Citation: Tyrnenopoulou, P.; Boufis, P.T.; Fthenakis, G.C.; Papadopoulos, E. Interactions between Parasitic Infections and Reproductive Efficiency in Horses. Parasitologia 2021, 1, 148-157. https://doi.org/ $10.3390 /$ parasitologia1030016

Academic Editor: Geoff Hide

Received: 22 June 2021

Accepted: 12 August 2021

Published: 13 August 2021

Publisher's Note: MDPI stays neutral with regard to jurisdictional claims in published maps and institutional affiliations.

Copyright: (c) 2021 by the authors. Licensee MDPI, Basel, Switzerland. This article is an open access article distributed under the terms and conditions of the Creative Commons Attribution (CC BY) license (https:// creativecommons.org/licenses/by/ $4.0 /)$.

\begin{abstract}
Parasites remain a significant threat to horses' health and welfare. The present paper reviews and discusses interactions between parasitic infections and reproductive efficiency in horses. The manuscript describes the interactions in a structured way, presenting the infecting parasites and the respective effects in the reproductive activity of horses. The following stages of the reproductive cycle are covered: ovarian activity and relevant body condition, breeding management (including effects in mares and stallions), pregnancy and neonatal period. A separate section covers the topic of transmission of pathogens to horses through parasites. Finally, parasite control strategies in relation to reproductive activity (strategies for breeding mares and foals) are discussed. Understanding the causality of impaired reproductive performance is essential in terms of maintaining productivity and efficient stud breeding strategies. Further collaboration of parasitologists, stud managers and veterinarians is necessary in order to implement novel control strategies with a greater emphasis on the emerging challenges.
\end{abstract}

Keywords: breeding; control; foal; helminth; horse; infection; mare; parasite; reproduction; Strongylus

\section{Introduction}

During the past 50 years, significant changes have occurred in the equine industry around the world [1]. The liberalisation of rules regarding horse breeding and the increased diversity of equestrian activities have resulted in a rise in the number of horse breeds and breed registries [2,3]. Stallion and mare reproductive efficiency levels are among the core components of the economy of the equine industry [4-6]. Improving our understanding of the causes and consequences of impaired reproductive performance in horses is, therefore, of prime interest.

Parasitic infections are ubiquitous in horses and consequently represent a significant component in terms of implementing appropriate management practices in those animals [7]. Anthelmintic resistance has been reported in worms recovered from horses [8,9]. Nevertheless, until recently, protocols for the administration of anthelmintics in horses have been based on the exclusive and regular use of anthelmintic agents [10]. Research data indicate that surveillance-based control programmes and regular faecal egg counts are necessary for determining when treatment is needed, hence reducing the reliance on anthelmintic treatments [11,12].

The present paper reviews and discusses interactions between parasitic infections and reproductive efficiency in horses.

\section{Ovarian Activity and Relevant Body Condition}

The prevention and control of parasitic infections are particularly important in horses, as they affect reproductive ability $[13,14]$. Early studies have highlighted nutrition as an important factor in the reproductive performance of various species; a minimum level of 
body fat is required to ensure normal reproductive activity in mammals [15]. Ovarian inactivity is a significant cause of infertility in breeding mares and it has been long associated with the low body condition of the animals [4]. Although a relationship between parasite load and body condition is not always easy to demonstrate and predict [16], particularly due to the variation in energy acquisition by horses, ovarian inactivity with anoestrus has been recorded in mares debilitated from intense parasitism that had brought the animals to a poor body condition [17-19].

Twin pregnancy in horses is often associated with complications; hence, it is not welcome. Mares carrying twins frequently lose one or both foetuses at an early or later stage of gestation and are more likely to suffer dystocia [20].

\section{Breeding Management}

Diseases caused by pathogens potentially transmitted during breeding cause significant concern to equine veterinarians [21]. Whether fertilisation would be achieved through mating or artificial insemination [2], some of these pathogens are particularly infective and can be transmitted between animals during direct horse-to-horse contact, through the use of contaminated semen or by indirect venereal contact, by means of contaminated equipment for semen collection and processing (including artificial vaginas and breeding phantoms) or even personnel (contaminated hands and clothing) participating in the semen collection process.

Trypanosoma equiperdum is a flagellate parasite, the causal agent of dourine, and the only protozoan pathogen causing a venereal disease in horses [22,23], as well as the only trypanosome not transmitted by an invertebrate vector. The disease is considered to have been eradicated in some countries of the world; cases of the disease are still diagnosed and reported in various countries in Asia, Africa, Central and South America and Russia [24]. In some countries of Europe, cases of dourine have not been reported for a long time (Portugal since 1925, Poland since 1951, Croatia since 1952, Czech Republic 1952, Hungary 1952, Bulgaria 1953, Spain 1955, France 1958, Greece since 1960) [25]. Nevertheless, during the previous decade, cases of the diseases were diagnosed in some countries of Southern and Eastern Europe [26,27].

Transmission of the parasite follows its presence in the seminal fluid and the mucous exudates of the penis and its sheath. Stallions are usually affected during the mating of mares, in which the organism was present in the vaginal mucus $[23,25]$. Clinical manifestations of dourine associated with the reproductive system include gelatinous infiltration in the vulva, the vaginal mucosa and the uterus, often coupled with non-painful oedema of the mammary glands in mares. In stallions, clinical sign can vary from a slight thickening of the scrotum, sheath and testicular tunica to the development of tough mass(es) of sclerotic tissue potentially resulting in testicular malformation [28]. Foals can become infected through the oral, nasal or conjunctival mucosa at birth, when coming in contact with vaginal discharge. Thenceforth, these infected foals can spread the organism further at later stages of their life [29], thus contributing to the dissemination of the parasite. Transmission to foals by ingestion of colostrum or milk is rare [30,31].

Among the common nematode parasites of horses, Oxyuris equi is widely distributed, historically throughout juvenile and immature populations of animals [32]. O. equi infection is often considered to be non-pathogenic; however, the local irritant effect of the eggs of the helminth deposited in the perineal region can cause considerable distress to an affected horse [33]. The intense itching by the irritant effect of the parasites may cause restlessness and impaired feeding, potentially leading to the deterioration of body condition.

With regard to stallions, it is noteworthy that the larvae of Habronema spp. or Draschia megastoma present on mucocutaneous junctions of the prepuce and penis, can cause ulcerated granulomatous lesions in those sites [34] that may lead to penile prolapse and reproductive disorders in stallions [35,36]. Moreover, Setaria equina, a filarioid nematode living in the abdominal cavity of horses is not considered to be pathogenic; however, some 
reports have presented incorrect migration of the parasite to the testes of stallions, which concluded with long-standing orchitis $[37,38]$.

\section{Pregnancy}

In horses, the causal agents of abortion and foetopathy include a wide range of mainly bacterial and viral pathogens [39-41], although parasitic agents are also implicated in their aetiology.

Neospora caninum and Neospora hughesi are intracellular protozoan parasites responsible for reproductive losses in horses. Cases of abortion caused by N. caninum may be misdiagnosed to be caused by Toxoplasma gondii, as also reported in other species [42,43]. Seroprevalence of the infection has been found to vary widely, from $0 \%$ to $85 \%$ [44-47]. In horses, the infection usually causes a subclinical disease; nevertheless, less often, it can result in abortion. Further, transplacental infection of a borne foetus can occur that may later lead to stillbirth $[44,46,48,49]$, although a case of congenital neosporosis has been reported in a one-month-old foal [50].

Less frequently, cases of infection by microsporidia (Encephalitozoon spp.) have also been reported, associated with placentitis and subsequent abortion in horses [51]. Nevertheless, although these parasites have an abortifacient effect in mares [52,53], there is little research regarding their significance in horses [54]. A case of infection with Encephalitozoon cuniculi associated with necrotising placentitis and abortion at the final stage of gestation has been reported [52].

Acanthamoeba spp. are protozoan species present in the environment [55]. Infections with amoebae generally occur through inhalations of cysts or exposure of skin lesions to contaminated elements of the environment followed by a haematogenous spreading of the parasite to the rest of the animal. Placentitis associated with Acanthamoeba hatchetti infection has been reported [56]; potential transmission scenarios of this organism include mechanical transport by setae or localised vascular invasion in the uterus.

Babesia caballi and Theileria equi are protozoan parasites, primarily transmitted by ixodid ticks (Rhipicephalus spp., Amblyomma spp., Dermacentor spp.) and infecting the horses. Rarely, these organisms can cause transplacental infection, followed by abortion or, alternatively, the birth of infected foals, which may occasionally show signs of disease $[57,58]$. It is noteworthy that in areas where T. equi is endemic, this organism is considered to be the major cause of equine abortions [57].

\section{Neonatal Period}

Strongyloides westeri is the first nematode parasite to infect foals and achieve patency, events that occur from the 3 rd to the 20th day of life [59]. Infection by S. westeri can be achieved by means of three potential routes. Lactogenic transmission is considered the most significant route of infection in foals; third-stage larvae, arrested within body tissues of the mare, are reactivated and migrate to the mammary glands and are transmitted to foals through the milk [60,61]. Alternatively, foals can also ingest infective free-living larvae or may experience percutaneous infection [62,63].

Young foals ( $<2$ months) are exposed to infection by Parascaris spp., although primarily animals over the age of 2 months and until weaning may be infected with this helminth. This parasite is considered as the most important parasite in foals; adult P. equorum and their larval stages are pathogenic for foals [64]. The infection is associated with respiratory disease, abnormal growth, colic, intestinal impaction or perforation, peritonitis and subsequent death [65-67]. An incident of jejunal impaction in a foal, caused by this parasite after administration of pyrantel pamoate, has also been described by Schusser et al. [68].

Regarding other parasites, cyathostomin infection is associated with clinical disease (poor growth, weight loss and diarrhoea) in older foals [69]; acute colitis may result from mass eruption of larval stages, throughout the grazing season, due to pasture larval contamination [70]. Anoplocephala perfoliata is a common equine tapeworm in the terminal part of the ileum and caecum associated with an increased risk of colic in adult horses and 
in older foals at the end of the grazing season [71,72]. Cryptosporidiosis (Cryptosporidium spp.) has been associated with foal diarrhea in immunocompromised animals [73-75]. Oocysts of Eimeria leuckarti have also been identified in faecal samples from foals. E. leuckarti has been incriminated as the cause of an intermittent diarrhoea, but the significance of this parasite is not fully known [76]. Gasterophilus spp. and O. equi do not achieve patency in foals younger than 2 months, and thus clinical signs characteristic of these parasitoses would not normally be expected [60].

During the neonatal period, foal health is fragile and these animals are particularly susceptible to pathogens. Hence, even mild parasitic burdens or the presence of strains with increased pathogenicity can lead to suboptimal growth and delayed development of foals.

\section{Transmission of Pathogens to Horses through Parasites}

Many arthropods (flies, midges, ticks, etc.) can transmit various pathogens, which may cause various reproductive disorders in horses [77]. Such examples include Trypanosoma evansi, which is reported to be mechanically transmitted in several ways; via biting or sucking insects (Tabanus, Haematobia, Hippobosca and Stomoxys), leaf nosed bats, carnivores, as well as by fomites [78]. Transplacental transmission has also been documented, but the mechanism responsible for crossing the placental barrier needs to be elucidated in greater depth [79].

The trematode helminthes Acanthatrium sp. and Lecithodendrium sp. can serve as vectors for Neorickettsia risticii, the agent of Potomac horse fever [80]. The disease occurs infrequently and can be associated with spontaneous abortion, although no evidence of placentitis has been reported in such cases [81,82].

In recent years, the terms 'mare reproductive loss syndrome' [83] and 'equine amnionitis and foetal loss' [84] have been used to describe abortions occurring during the midto-late stage of gestation without specific clinical or laboratory findings, with a view to differentiate them from other common causes of equine pregnancy loss [85]. In such cases, pasture exposure to eastern tent caterpillars (Malacosoma americanum) and processionary caterpillars (Ochragaster lunifer) has been considered as an important risk factor for the above conditions; moreover, abortions have been experimentally reproduced [86], although the mechanism causing abortion is still unknown. Setae of the processionary caterpillar were documented to migrate from the gastrointestinal tracts of exposed mares into the uterus and foetal membranes, ultimately causing abortion [86].

\section{Parasite Control Strategies in Relation to Reproductive Activity}

\subsection{Control Strategies for Breeding Mares}

Anthelmintic resistance to equine parasites is still a substantial challenge for veterinarians active in the field $[87,88]$. Previous studies have reported resistance (confirmed or suspected) of small strongyles to benzimidazoles, pyrantel salts and macrocyclic lactones [89-93]. Cyathostomins have nowadays become a growing concern, as in the past their pathogenic potential was over-shadowed by Strongylus vulgaris; features of the infection are not specific and can vary from weight loss and diarrhoea to severe inflammatory enteropathy occasionally leading to death [94,95]. It is also noteworthy that anthelmintic resistance among large strongyle species, which may be a cause of high mortality rate, has been infrequently reported in recent years, although some recent evidence points out to a potential re-emergence of the problem, as the result of inappropriate parasite control strategies [7,96,97]. In this context, therefore, broodmares are the most important animals for considering when designing control programmes in stud farms.

Targeted anthelmintic treatments in broodmares are principally focused on cyathostomin control [98]. As mature horses, broodmares vary in their innate resistance to cyathostomin infection and their potential for strongyle egg shedding. Grazing horses can be infected by cyathostomins, which often may account for up to $95 \%$ to $100 \%$ of the total worm burden in an individual $[7,99]$. Other helminthes often recovered from adult horses 
include P. equorum, O. equi and the large strongyle species: S. vulgaris, S. edentatus, S. equinus and Triodontophorus spp. Moreover, A. perfoliata can also be recovered, from $20 \%$ to $80 \%$ of animals $[72,100]$.

Control of parasitic infections can effectively be performed by administration of macrocyclic lactones during the last stage of pregnancy, immediately prior to foaling. The scheme aims to reduce the risk of transfer of S. westeri to newborn foals through milk [101]. S. westeri patency and foal heat diarrhoea can develop concurrently during the second week of the life of foals, although no causality has thus far been established [64]. Therefore, the practice of routine anthelmintic treatment, in order to prevent Strongyloides-associated diarrhoea, could no longer be sustained in properly managed stud farms. During targeted regimes, administration of anthelmintics should be performed after confirming evidence of the presence of helminth eggs in the faeces of animals.

It can be assumed that horses grazing together are infected with the same parasitic population. Nevertheless, large differences between them have been identified in the amount of parasitic eggs excreted in their faeces [102]. This distribution of parasite egg shedding among hosts is similar for all parasitic species and is referred to as 'over-dispersion'. Consequently, protocols for the administration of anthelmintic treatments can be individualised among adult animals (i.e., $>3$ years of age), if the number of eggs shed in faecal samples is determined, usually after performing faecal egg counts. In general, examination of faecal samples from at least six animals in the group should be carried out at the time of treatment and 14 days later [103].

As mentioned above, the selective treatment strategies for the parasites of interest can be incorporated into the annual life cycle of a horse, which runs according to the gestation of the animal. In this context, one- or two-yearly treatments suffice for the prevention of infection by large strongyles [104]. With regard to broodmares shedding a low number of eggs, treatment with ivermectin (concurrently with or without praziquantel) in the autumn and in the spring, immediately before foaling or immediately post-partum, is considered a safe, useful and sustainable method [104-106].

\subsection{Control Strategies for Foals}

As mentioned above, young horses are susceptible to a wide range of parasites. Selective, surveillance-based helminth control strategies based on the evaluation of each individual animal's susceptibility to parasitism cannot be applied in young horses [64]. Innate differences in the susceptibility of the hosts do not have adequate competency through the immature immune system of foals [60].

In general, before the establishment of acquired immunity, effective larvicidal anthelmintic protocols are important to ensuring the effective control of all stages of ascarid infections in young foals. However, the resistance to antiparasitic compounds of helminthes recovered from foals [107-109] complicates the design and establishment of appropriate anthelmintic schemes for foals. In any case, the first anthelmintic treatment should not be performed later than the age of two months [104]. Moreover, as increased doses of drugs have often been recommended for foals, it is noteworthy that administration of unlicenced doses of drugs to horses is the responsibility and concern of the prescribing veterinarian with regard to the safety of the drug and maintenance of increased withdrawal periods. Finally, some drugs (e.g., moxidectin) are not licenced for use in young foals, which sets further hindrances in formulating anthelmintic programmes.

S. westeri and P. equorum are the helminthes most frequently infecting horses in those ages. S. westeri often causes an asymptomatic infection, but P. equorum can cause more serious problems. Pyrantel and macrocyclic lactones are effective against adult parasites, while fenbendazole has been reported to show activity against adults and larvae of some parasites [110]. Challenges are also present in controlling the parasites; for example, $P$. equorum is a dose-limiting parasite for many anthelmintics, as it has a lower threshold for the development of anthelmintic resistance [60]. 
Tapeworm infection should be taken into consideration in older foals and at the end of the grazing season. Foals should be treated against $A$. perfoliata during the first autumn or winter of their life [111].

Gasterophilus spp. and O. equi infections are seasonal and sporadic and usually affect older foals [60]. Macrocyclic lactones are the only currently marketed class of equine anthelmintics with efficacy against $O$. equi. There are many anecdotal reports of pinworms being resistant to macrocyclic lactones; however, there are only a few documented cases in the literature thus far $[95,112]$. The larval stages of Gasterophilus are highly susceptible to macrocyclic lactones and will be eliminated during regular deworming with these drugs. As fly activity ceases with the first frosts, an appropriate treatment in late autumn would remove all larvae present within horses. A well-established programme throughout the neighbouring equine facilities is also necessary for control of these parasites.

\section{Concluding Remarks}

Parasites in horses remain a significant threat to the health and welfare of these animals. The present review discussed the possible direct and indirect effects of parasitism on the reproductive efficiency of horses. Understanding the causality of impaired reproductive performance is essential in terms of maintaining productivity and efficient stud breeding strategies. Further collaboration of parasitologists, stud managers and veterinarians is necessary in order to implement novel control strategies with a greater emphasis on the emerging challenges.

Author Contributions: Conceptualization, P.T. and E.P.; writing—original draft preparation, P.T. and P.T.B.; writing - review and editing, P.T., G.C.F. and E.P. All authors have read and agreed to the published version of the manuscript.

Funding: Not applicable.

Institutional Review Board Statement: Not applicable.

Informed Consent Statement: Not applicable.

Data Availability Statement: No new data presented.

Conflicts of Interest: The authors declare no conflict of interest.

\section{References}

1. Timoney, P.J. Factors influencing the international spread of equine diseases. Vet. Clin. N. Am. Equine Pract. 2000, 16, 537-551. [CrossRef]

2. Aurich, J.; Aurich, C. Developments in European horse breeding and consequences for veterinarians in equine reproduction. Reprod. Domest. Anim. 2006, 41, 275-279. [CrossRef]

3. Samper, J.C.; Pycock, J.F.; McKinnon, A.O. Current Therapy in Equine Reproduction; Saunders: Philadelphia, PA, USA, 2007.

4. Henneke, D.R.; Potter, G.D.; Kreider, J.L. Body condition during pregnancy and lactation and reproductive efficiency of mares. Theriogenology 1984, 21, 897-909. [CrossRef]

5. Davison, K.E.; Potter, G.D.; Greene, L.W.; Evans, J.W.; McMullan, W.C. Lactation and reproductive performance of mares fed added dietary fat during late gestation and early lactation. J. Equine Vet. Sci. 1991, 11, 111-115. [CrossRef]

6. Baker, C.B.; Little, T.V.; McDowell, K.J. The live foaling rate per cycle in mares. Equine Vet. J. 1993, 15, 28-30. [CrossRef]

7. Nielsen, M.K. Sustainable equine parasite control: Perspectives and research needs. Vet. Parasitol. 2012, 185, 32-44. [CrossRef]

8. Reinemeyer, C.R. Anthelmintic resistance in non-strongylid parasites of horses. Vet. Parasitol. 2012, 185, 9-15. [CrossRef]

9. Peregrine, A.S.; Molento, M.B.; Kaplan, R.M.; Nielsen, M.K. Anthelmintic resistance in important parasites of horses: Does it really matter? Vet. Parasitol. 2014, 201, 1-8. [CrossRef]

10. Von Samson-Himmelstjerna, G. Anthelmintic resistance in equine parasites-Detection, potential clinical relevance and implications for control. Vet. Parasitol. 2012, 185, 2-8. [CrossRef]

11. Kaplan, R.M.; Vidyashankar, A.N. An inconvenient truth: Global warming and anthelmintic resistance. Vet. Parasitol. 2012, 186, 70-78. [CrossRef]

12. Nielsen, M.K.; Reinemeyer, C.R.; Sellon, D.C. Nematodes. In Equine Infectious Diseases, 2nd ed.; Sellon, D.C., Long, M.T., Eds.; Saunders: Philadelphia, PA, USA, 2014; pp. 475-489.

13. Krecek, R.C.; Waller, P.J. Towards the implementation of the "basket of options" approach to helminth parasite control of livestock: Emphasis on the tropics/subtropics. Vet. Parasitol. 2006, 139, 270-282. [CrossRef] 
14. Swann, W.J. Improving the welfare of working equine animals in developing countries. Appl. Anim. Behav. Sci. 2006, 100, 148-151. [CrossRef]

15. Frisch, R.E. Pubertal adipose tissue: Is it necessary for normal sexual maturation? Evidence from the rat and human female. Fed. Proc. 1980, 39, 2395-2400. [PubMed]

16. Debeffe, L.; McLoughlin, P.D.; Medill, S.A.; Stewart, K.; Andres, D.; Shury, T.; Wagner, B.; Jenkins, E.; Gilleard, J.S.; Poissant, J. Negative covariance between parasite load and body condition in a population of feral horses. Parasitology 2016, 143, 983-997. [CrossRef] [PubMed]

17. Watson, E.D. Infertility in the mare. J. Comp. Pathol. 1994, 111, 333-351. [CrossRef]

18. Ali, A.; Alamaary, M.; Al-Sobayil, F. Reproductive performance of Arab mares in the Kingdom of Saudi Arabia. Tierarztl Prax. Ausg. G Grosstiere Nutztiere 2014, 42, 145-149.

19. Ali, A.; Alamaary, M.; Al-Sobayil, F. Clinical and laboratory findings in barren Arabian mares. Comp. Clin. Pathol. 2021, 30, 35-40. [CrossRef]

20. McKinnon, A.O. Twin reduction techniques. In Current Therapy in Equine Reproduction; Samper, J.C., Pycock, J.F., McKinnon, A.O., Eds.; Saunders: St. Louis, MO, USA, 2007; pp. 357-373.

21. Blanchard, T.L.; Kenney, R.M.; Timoney, P.J. Venereal disease. Vet. Clin. N. Am. Equine Pract. 1992, 8, 191-203. [CrossRef]

22. Brinsko, S.; Blanchard, T.; Varner, D.; Schumacher, J.; Love, C.; Hinrichs, K.; Hartman, D. Examination of the stallion for breeding soundness. In Manual of Equine Reproduction, 3rd ed.; Brinsko, S.P., Blanchard, T.L., Varner, D.D., Schumacher, J., Love, C.C., Hinrichs, K., Hartman, D.L., Eds.; Elsevier: Amsterdam, The Netherlands, 2011; pp. 176-206.

23. Gizaw, Y.; Megersa, M.; Fayera, T. Dourine: A neglected disease of equids. Trop. Anim. Health Prod. 2017, 49, 887-897. [CrossRef]

24. Suganuma, K.; Narantsatsral, S.; Battur, B.; Yamasaki, S.; Otgonsuren, D.; Musinguzi, S.P.; Davaasuren, B.; Battsetseg, B.; Inoue, N. Isolation, cultivation and molecular characterization of a new Trypanosoma equiperdum strain in Mongolia. Parasites Vectors 2016, 9 , 1-9. [CrossRef]

25. World Organisation for Animal Health. Dourine (Infection with Trypanosoma equiperdum). 2021. Available online: https: / / www.oie.int/app/uploads/2021/03/dourine.pdf (accessed on 10 June 2021).

26. Calistri, P.; Narcisi, V.; Atzeni, M.; De Massis, F.; Tittarelli, M.; Mercante, M.T.; Ruggieri, E.; Scacchia, M. Dourine reemergence in Italy. J. Equine Vet. Sci. 2013, 33, 83-89. [CrossRef]

27. Sidney, R.; McAndrew, G.; James, C.; Richard, N. Dourine-An Emerging Venereal Threat to European Horses; AHT/BEVA/DEFRA Equine Quarterly Disease Surveillance Report; Animal Health Trust: Newmarket, UK, 2013; Volume 6, p. 7.

28. Vulpiani, M.P.; Carvelli, A.; Giansante, D.; Iannino, F.; Paganico, D.; Ferri, N. Reemergence of dourine in Italy: Clinical cases in some positive horses. J. Equine Vet. Sci. 2013, 33, 468-474. [CrossRef]

29. Constable, P.; Hinchcliff, K.; Done, S.; Grünberg, W. Veterinary Medicine A Textbook of the Diseases of Cattle, Horses, Sheep, Pigs and Goats, 11th ed.; Elsevier: Amsterdam, The Netherlands, 2017.

30. William, B.L.; Steven, H.S. Infectious diseases of breeding stallion. In Current Therapy in Large Animal Theriogenology, 2nd ed.; Youngquist, R.S., Threlfall, W.R., Eds.; Saunders: Philadelphia, PA, USA, 2007; pp. 15-23.

31. Pascucci, I.; Di Provvido, A.; Cammà, C.; Di Francesco, G.; Calistri, P.; Tittarelli, M.; Ferri, N.; Scacchia, M.; Caporale, V. Diagnosis of dourine in outbreaks in Italy. Vet. Parasitol. 2013, 193, 30-38. [CrossRef]

32. Lyons, E.T.; Tolliver, S.C.; Drudge, J.H.; Swerczek, T.W.; Crowe, M.W. Prevalence of some internal parasites recovered at necropsy of thoroughbreds born in 1982 in Kentucky. Am. J. Vet. Res. 1985, 46, 679-683.

33. Behera, H.K.; Jena, G.R.; Kumar, D.; Mohapatra, P.; Mishra, S.K.; Sahoo, R.; Dalei, N. Infestation of Oxyuris equi in horse and its successful therapeutic management. J. Pharma Innov. 2017, 6, 387-389.

34. Tyrnenopoulou, P.; Diakakis, N.; Psalla, D.; Traversa, D.; Papadopoulos, E.; Antonakakis, M. Successful surgical management of eosinophilic granuloma on the urethral process of a gelding associated with Habronema spp. infection. Equine Vet. Educ. 2019, 31, e1-e4. [CrossRef]

35. Edwards, J.F. Pathologic conditions of the stallion reproductive tract. Anim. Reprod. Sci. 2008, 107, 197-207. [CrossRef] [PubMed]

36. McCue, P.M. Hemospermia. In Equine Reproductive Procedures, 2nd ed.; Dascanio, J., McCue, P., Eds.; Wiley: Hoboken, NJ, USA, 2021.

37. Marino, G.; Zanghi, A.; Quartuccio, M.; Cristarella, S.; Giuseppe, M.; Catone, G. Equine testicular lesions related to invasion by nematodes. J. Equine Vet. Sci. 2009, 29, 728-733. [CrossRef]

38. Kornaś, S.; Pozor, M.; Okólski, A.; Nowosad, B. Przypadek obecności nicienia Setaria equina w jamie pochwowej worka mosznowego ogiera. Wiad. Parazytol. 2010, 56, 319-321. [PubMed]

39. Laugier, C.; Foucher, N.; Sevin, C.; Leon, A.; Tapprest, J. A 24-year retrospective study of equine abortion in Normandy (France). J. Equine Vet. Sci. 2011, 31, 116-123. [CrossRef]

40. Canisso, I.F.; Ball, B.A.; Erol, E.; Squires, E.L.; Troedsson, M.H.; Dact, D. Comprehensive review on equine placentitis. Proc. Am. Assoc. Equine Pract. 2015, 61, 490-509.

41. Schulman, M.L.; Becker, A.; Van der Merwe, B.D.; Guthrie, A.J.; Stout, T.A.E. Epidemiology and reproductive outcomes of EHV-1 abortion epizootics in unvaccinated Thoroughbred mares in South Africa. Equine Vet. J. 2015, 47, 155-159. [CrossRef]

42. Weiss, L.M.; Dubey, J.P. Toxoplasmosis: A history of clinical observations. Int. J. Parasitol. 2009, 39, 895-901. [CrossRef] [PubMed]

43. Shaapan, R.M. The common zoonotic protozoal diseases causing abortion. J. Parasit. Dis. 2016, 40, 1116-1129. [CrossRef] 
44. Dubey, J.P.; Porterfield, M.L. Toxoplasma-like sporozoa in an aborted equine fetus. J. Am. Vet. Med. Assoc. 1986, 188, 1312-1313. [PubMed]

45. Pitel, P.-H.; Prosnost, S.; Romanel, S.; Rhulliez, P.; Fortier, S.; Ballet, J.J. Prevalence of antibodies to Neospora caninum in horses in France. Equine Vet. J. 2001, 33, 205-207. [CrossRef] [PubMed]

46. Jakubek, E.B.; Lundén, A.; Uggla, A. Seroprevalences of Toxoplasma gondii and Neospora sp. infections in Swedish horses. Vet. Parasitol. 2006, 138, 194-199. [CrossRef] [PubMed]

47. Antonello, A.M.; Pivoto, F.L.; Camillo, G.; Braunig, P.; Sangioni, L.A.; Pompermayer, E.; Vogel, F.S.F. The importance of vertical transmission of Neospora sp. in naturally infected horses. Vet. Parasitol. 2012, 187, 367-370. [CrossRef]

48. Gray, M.L.; Harmon, B.G.; Sales, L.; Dubey, J.P. Visceral neosporosis in a 10-year-old horse. J. Vet. Diagn. Investig. 1996, 8, 130-133. [CrossRef]

49. Tassi, P. Toxoplasma gondii infection in horses. A review. Parassitologia 2007, 49, 7-15. [PubMed]

50. Lindsay, D.S.; Steinberg, H.; Dubielzig, R.R.; Semrad, S.D.; Konkle, D.M.; Miller, P.E.; Blagburn, B.L. Central nervous system neosporosis in a foal. J. Vet. Diagn. Investig. 1996, 8, 507-510. [CrossRef]

51. Didier, E.S.; Stovall, M.E.; Green, L.C.; Brindley, P.J.; Sestak, K.; Didier, P.J. Epidemiology of microsporidiosis: Sources and modes of transmission. Vet. Parasitol. 2004, 126, 145-166. [CrossRef]

52. Patterson-Kane, J.C.; Caplazi, P.; Rurangirwa, F.; Tramontin, R.R.; Wolfsdorf, K. Encephalitozoon cuniculi placentitis and abortion in a quarterhorse mare. J. Vet. Diagn. Investig. 2003, 15, 57-59. [CrossRef] [PubMed]

53. Szeredi, L.; Pospischil, A.; Dencso, L.; Mathis, A.; Dobos-Kovacs, M. Case of equine abortion caused by Encephalitozoon sp. Acta Vet. Hung. 2007, 55, 525-532. [CrossRef]

54. Laatamna, A.E.; Wagnerová, P.; Sak, B.; Květoňová, D.; Xiao, L.; Rost, M.; McEvoy, J.; Saadi, A.R.; Aissi, M.; Kváč, M. Microsporidia and Cryptosporidium in horses and donkeys in Algeria: Detection of a novel Cryptosporidium hominis subtype family (Ik) in a horse Vet. Parasitol. 2015, 208, 135-142. [CrossRef]

55. Visvesvara, G.S.; Moura, H.; Schuster, F.L. Pathogenic and opportunistic free-living amoebae: Acanthamoeba spp., Balamuthia mandrillaris, Naegleria fowleri, and Sappinia diploidea. FEMS Immunol. Med. Microbiol. 2007, 50, 1-26. [CrossRef]

56. Begg, A.P.; Todhunter, K.; Donahoe, S.L.; Krockenberger, M.; Slapeta, J. Severe amoebic placentitis in a horse caused by an Acanthamoeba hatchetti isolate identified using next-generation sequencing. J. Clin. Microbiol. 2014, 52, 3101-3104. [CrossRef]

57. de Sousa, S.H.; Paludo, G.R.; Freschi, C.R.; Machado, R.Z.; de Castro, M.B. Theileria equi infection causing abortion in a mare in Brazil. Vet. Parasitol. Reg. Stud. Rep. 2017, 8, 113-116. [CrossRef] [PubMed]

58. Tirosh-Levy, S.; Gottlieb, Y.; Mimoun, L.; Mazuz, M.L.; Steinman, A. Transplacental transmission of Theileria equi is not a common cause of abortions and infection of foals in Israel. Animals 2020, 10, 341. [CrossRef]

59. Lyons, E.T.; Drudge, J.H.; Tolliver, S.C. On the life cycle of Strongyloides westeri in the equine. J. Parasitol. 1973, 59, 780-787. [CrossRef] [PubMed]

60. Reinemeyer, C.R.; Nielsen, M.K. Control of helminth parasites in juvenile horses. Equine Vet. Educ. 2017, 29, 225-232. [CrossRef]

61. Thamsborg, S.M.; Ketzis, J.; Horii, Y.; Matthews, J.B. Strongyloides spp. infections of veterinary importance. Parasitology 2017, 144, 274-284. [CrossRef]

62. DiPietro, J.A. A review of Strongyloides westeri infections in foals. Equine Pract. 1989, 11, 35-40.

63. Dewes, H.F.; Townsend, K.G. Further observations on Strongyloides westeri dermatitis: Recovery of larvae from soil and bedding, and survival in treated sites. N. Z. Vet. J. 1990, 38, 34-37. [CrossRef]

64. Nielsen, M.K.; Pfister, K.; von Samson-Himmelstjerna, G. Selective therapy in equine parasite control—Application and limitations. Vet. Parasitol. 2014, 202, 95-103. [CrossRef] [PubMed]

65. Clayton, H.M.; Duncan, J.L.; Dargie, J.D. Pathophysiological changes associated with Parascaris equorum infection in the foal. Equine Vet. J. 1980, 12, 23-25. [CrossRef] [PubMed]

66. Southwood, L.L.; Ragle, C.A.; Snyder, J.R.; Hendrickson, D.A. Surgical treatment of ascarid impactions in horses and foals. Proc. Am. Assoc. Equine Pract. 1996, 42, 258.

67. Cribb, N.C.; Cote, N.M.; Boure, L.P.; Peregrine, A.S. Acute small intestinal obstruction associated with Parascaris equorum infection in young horses: 25 cases (1985-2004). N. Z. Vet. J. 2006, 54, 338-343. [CrossRef] [PubMed]

68. Schusser, G.; Kopf, N.; Prosl, H. Impaction (obturation intestini jejuni) of the small intestine by Parascaris equorum caused by the administration of pyrantel pamoate in a 5-months-old-foal. Wien. Tierartzl. Monatssch. 1988, 75, 152-157.

69. Corning, S. Equine cyathostomins: A review of biology, clinical significance and therapy. Parasites Vectors 2009, 2, S1. [CrossRef] [PubMed]

70. Nielsen, M.K.; Lyons, E.T. Encysted cyathostomin larvae in foals-Progression of stages and the effect of seasonality. Vet. Parasitol. 2017, 236, 108-112. [CrossRef] [PubMed]

71. Barclay, W.P.; Phillips, T.N.; Foerner, J.J. Intussusception associated with Anoplocephala perfoliata infection in five horses. J. Am. Vet. Med. Assoc. 1982, 180, 752-753.

72. Slater, R.; Frau, A.; Hodgkinson, J.; Archer, D.; Probert, C.A. Comparison of the colonic microbiome and volatile organic compound metabolome of Anoplocephala perfoliata infected and non-infected horses: A pilot study. Animals 2021, 11, 755. [CrossRef]

73. Snyder, S.P.; England, J.J.; McChesney, A.E. Cryptosporidiosis in immunodeficient Arabian foals. Vet. Pathol. 1978, $15,12-17$. [CrossRef] [PubMed]

74. Gajadhar, A.A.; Caron, J.P.; Allen, J.R. Cryptosporidiosis in two foals. Can. Vet. J. 1985, 26, 132-134. [PubMed] 
75. Netherwood, T.; Wood, J.L.N.; Townsend, H.G.G.; Mumford, J.A.; Chanter, N. Foal diarrhea between 1991 and 1994 in the United Kingdom associated with Clostridium perfringens, rotavirus, Strongyloides westeri and Cryptosporidium spp. Epidemiol. Infect. 1996, 117, 375-383. [CrossRef]

76. Dubey, J.P.; Bauer, C. A review of Eimeria infections in horses and other equids. Vet. Parasitol. 2018, 256, 58-70. [CrossRef]

77. Onmaz, A.C.; Beutel, R.G.; Schneeberg, K.; Pavaloiu, A.N.; Komarek, A.; Van Den Hoven, R. Vectors and vector-borne diseases of horses. Vet. Res. Commun. 2013, 37, 65-81. [CrossRef]

78. Desquesnes, M.; Dargantes, A.; Lai, D.H.; Lun, Z.R.; Holzmuller, P.; Jittapalapong, S. Trypanosoma evansi and surra: A review and perspectives on transmission, epidemiology and control, impact, and zoonotic aspects. Biomed. Res. Int. 2013, $2013,321237$. [CrossRef]

79. Kumar, R.; Kumar, S.; Virmani, N.; Yadav, S.C. Transplacental transmission of Trypanosoma evansi from experimentally infected donkey mare to neonatal foal. J. Equine Vet. Sci. 2015, 35, 337-341. [CrossRef]

80. Pusterla, N.; Johnson, E.M.; Chae, J.S.; Madigan, J.E. Digenetic trematodes, Acanthatrium sp. and Lecithodendrium sp., as vectors of Neorickettsia risticii, the agent of Potomac horse fever. J. Helminthol. 2003, 77, 335-339. [CrossRef]

81. Smith, K.; Blunden, A.; Whitwell, K. A survey of equine abortion, stillbirth and neonatal death in the UK from 1988 to 1997. Equine Vet. J. 2003, 35, 496-501.

82. Coffman, E.A.; Abd-Eldaim, M.; Craig, L.E. Abortion in a horse following Neorickettsia risticii infection. J. Vet. Diagn. Investig. 2008, 20, 827-830. [CrossRef] [PubMed]

83. McDowell, K.J.; Webb, B.A.; Williams, N.M.; Donahue, J.M.; Newman, K.E.; Lindemann, M.D.; Horohov, D.W. The role of caterpillars in mare reproductive loss syndrome: A model for environmental causes of abortion. J. Anim. Sci. 2010, 88, 1379-1387. [CrossRef]

84. Todhunter, K.H.; Cawdell-Smith, A.J.; Begg, A.P.; Perkins, N.R.; Bryden, W.L. Caterpillars and equine fetal loss: Aspects of histopathology. Anim. Reprod. Sci. 2020, 121, S351-S352.

85. Cawdell-Smith, A.J.; Todhunter, K.H.; Anderson, S.T.; Perkins, N.R.; Bryden, W.L. Equine amnionitis and fetal loss: Mare abortion following experimental exposure to processionary caterpillars (Ochrogaster lunifer). Equine Vet. J. 2012, 44, 282-288. [CrossRef] [PubMed]

86. Todhunter, K.H.; Cawdell-Smith, A.J.; Bryden, W.L.; Perkins, N.R.; Begg, A.P. Processionary caterpillar setae and equine fetal loss: 1. Histopathology of experimentally exposed pregnant mares. Vet. Pathol. 2014, 51, 1117-1130. [CrossRef]

87. Køhler, P. The biochemical basis of anthelmintic action and resistance. Int. J. Parasitol. 2001, 31, 336-345. [CrossRef]

88. Matthews, J.B. Anthelmintic resistance in equine nematodes. Int. J. Parasitol. Drug Resist. 2014, 25, 310-315. [CrossRef]

89. Tarigo-Martinie, J.L.; Wyatt, A.R.; Kaplan, R.M. Prevalence and clinical implications of anthelmintic resistance in cyathostomes of horses. J. Am. Vet. Med. Assoc. 2001, 218, 1957-1960. [CrossRef]

90. Kaplan, R.M.; Klei, T.R.; Lyons, E.T.; Lester, G.; Courtney, C.K.; French, D.D.; Toliver, S.C.; Vidyashankar, A.N.; Zhao, Y. Prevalence of anthelmintic resistant cyathostomes on horse farms. J. Am. Vet. Med. Assoc. 2004, 225, 903-910. [CrossRef]

91. Von Samson-Himmelstjerna, G.; Fritzen, B.; Demelera, J.; Schürmann, S.; Rohn, K.; Schnieder, T.; Epe, C. Cases of reduced cyathostomin egg-reappearance period and failure of Parascaris equorum egg count reduction following ivermectin treatment as well as survey on pyrantel efficacy on German horse farms. Vet. Parasitol. 2007, 144, 74-80. [CrossRef]

92. Traversa, D.; Castagna, G.; Samson-Himmelstjerna, G.; Meloni, S.; Bartolini, R.; Geurden, T.; Pearce, M.C.; Woringer, E.; Besognet, B.; Milillo, P.; et al. Efficacy of major anthelmintics against horse cyathostomins in France. Vet. Parasitol. 2012, 188, 294-300. [CrossRef]

93. Tzelos, T.; Barbeito, J.S.; Nielsen, M.K.; Morgan, E.R.; Hodgkinson, J.E.; Matthews, J.B. Strongyle egg reappearance period after moxidectin treatment and its relationship with management factors in UK equine populations. Vet. Parasitol. 2017, 237, 70-76. [CrossRef]

94. Love, S.; Murphy, D.; Mellor, D. Pathogenicity of cyathostome infection. Vet. Parasitol. 1999, 85, 113-121. [CrossRef]

95. Sallé, G.; Cortet, J.; Bois, I.; Dubès, C.; Guyot-Sionest, Q.; Larrieu, C.; Landrin, V.; Majorel, G.; Wittreck, S.; Woringer, E.; et al. Risk factor analysis of equine strongyle resistance to anthelmintics. Int. J. Parasitol. Drugs Drug Resist. 2017, 7, 407-415. [CrossRef]

96. Nielsen, M.K.; Vidyashankar, A.N.; Olsen, S.N.; Monrad, J.; Thamsborg, S.M. Strongylus vulgaris associated with usage of selective therapy on Danish horse farms-is it reemerging? Vet. Parasitol. 2012, 189, 260-266. [CrossRef]

97. Tydén, E.; Enemark, H.L.; Franko, M.A.; Höglund, J.; Osterman-Lind, E. Prevalence of Strongylus vulgaris in horses after ten years of prescription usage of anthelmintics in Sweden. Vet. Parasitol. 2019, 2, 100013. [CrossRef]

98. Matthews, J.B. The future of helminth control in horses. Equine Vet. J. 2014, 46, 10-11. [CrossRef]

99. Peachey, L.E.; Molena, R.A.; Jenkins, T.P.; Di Cesare, A.; Traversa, D.; Hodgkinson, J.E.; Cantacessi, C. The relationships between faecal egg counts and gut microbial composition in UK Thoroughbreds infected by cyathostomins. Int. J. Parasitol. 2018, 48, 403-412. [CrossRef] [PubMed]

100. Gasser, R.B.; Williamson, R.M.C.; Beveridge, I. Anoplocephala perfoliata of horses—Significant scope for further research improved diagnosis and control. Parasitology 2005, 131, 1-13. [CrossRef]

101. Ludwig, K.G.; Craig, T.M.; Bowen, J.M.; Ansari, M.M.; Ley, W.B. Efficacy of ivermectin in controlling Strongyloides westeri infections in foals. Am. J. Vet. Res. 1983, 44, 314-316. [PubMed]

102. Nielsen, M.K.; Haaning, N.; Olsen, S.N. Strongyle egg shedding consistency in horses on farms using selective therapy in Denmark. Vet. Parasitol. 2006, 135, 333-335. [CrossRef] 
103. Coles, G.C.; Jackson, F.; Pomroy, W.E.; Prichard, R.K.; Von Samson-Himmelstjerna, G.; Silvestre, A.; Taylor, M.A.; Vercruysse, J. The detection of anthelmintic resistance in nematodes of veterinary importance. Vet. Parasitol. 2006, 136, 167-185. [CrossRef]

104. Vaala, W.; Houston, R. Parasite control strategies. In Interpretation of Equine Laboratory Diagnostics; Pusterla, N., Higgins, J., Eds.; Wiley: Hoboken, NJ, USA, 2021; pp. 301-319.

105. Schneider, S.; Pfister, K.; Becher, A.M.; Scheuerle, M.C. Strongyle infections and parasitic control strategies in German horses-A risk assessment. BMC Vet. Res. 2014, 10, 26. [CrossRef]

106. Misuno, E.; Clark, C.R.; Anderson, S.L.; Jenkins, E.; Wagner, B.; Dembek, K.; Petrie, L. Characteristics of parasitic egg shedding over a 1-year period in foals and their dams in 2 farms in central Saskatchewan. Can. Vet. J. 2018, 59, $284-292$.

107. Slocombe, J.O.; de Gannes, R.V.; Lake, M.C. Macrocyclic lactone-resistant Parascaris equorum on stud farms in Canada and effectiveness of fenbendazole and pyrantel pamoate. Vet. Parasitol. 2007, 145, 371-376. [CrossRef]

108. Veronesi, F.; Fioretti, D.P.; Genchi, C. Are macrocyclic lactones useful drugs for the treatment of Parascaris equorum infections in foals? Vet. Parasitol. 2010, 172, 164-167. [CrossRef]

109. Lyons, E.T.; Tolliver, S.C. Prevalence of patent Strongyloides westeri infections in Thoroughbred foals in 2014. Parasitol. Res. 2014, 113, 4163-4164. [CrossRef]

110. Reinemeyer, C.R.; Prado, J.C.; Nichols, E.C.; Marchiondo, A.A. Efficacy of pyrantel pamoate against a macrocyclic lactone-resistant isolate of Parascaris equorum in horses. Vet. Parasitol. 2010, 171, 111-115. [CrossRef]

111. Love, S.; Mair, T.S. Infectious diseases and parasitology. In Equine Medicine, Surgery and Reproduction, 2nd ed.; Mair, T., Love, S., Schumacher, J., Smith, R., Frazer, G., Eds.; Elsevier: Amsterdam, The Netherlands, 2011; pp. 399-422.

112. Wolf, D.; Hermosilla, C.; Taubert, A. Oxyuris equi: Lack of efficacy in treatment with macrocyclic lactones. Vet. Parasitol. 2014, 201, 163-168. [CrossRef] [PubMed] 